\title{
RET Signaling Is Required for Survival and Normal Function of Nonpeptidergic Nociceptors
}

\author{
Judith P. Golden, ${ }^{1}$ Masato Hoshi, ${ }^{2}$ Mohammed A. Nassar, ${ }^{8}$ Hideki Enomoto, ${ }^{7}$ John N. Wood, ${ }^{8,9}$ Jeffrey Milbrandt, ${ }^{3,6}$ \\ Robert W. Gereau IV, ${ }^{1,3}$ Eugene M. Johnson Jr, ${ }^{3,4,5}$ and Sanjay Jain ${ }^{2,3,6}$ \\ ${ }^{1}$ Washington University Pain Center, Department of Anesthesiology, ${ }^{2}$ Renal Division, Department of Medicine, ${ }^{3}$ Hope Center for Neurological Disorders, \\ and Departments of ${ }^{4}$ Neurology, ${ }^{5}$ Developmental Biology, and ${ }^{6}$ Pathology and Immunology, Washington University School of Medicine, St. Louis, Missouri \\ 63110, ${ }^{7}$ Laboratory for Neuronal Differentiation and Regeneration, RIKEN Center for Developmental Biology, Kobe 650-0047, Japan, ${ }^{8}$ Molecular \\ Nociception Group, Department of Biology, University College London, London WC1E 6BT, United Kingdom, and ${ }^{9}$ Department of Molecular Medicine, \\ Seoul National University, Seoul 151-742, Korea
}

Small unmyelinated sensory neurons classified as nociceptors are divided into two subpopulations based on phenotypic differences, including expression of neurotrophic factor receptors. Approximately half of unmyelinated nociceptors express the NGF receptor TrkA, and half express the GDNF family ligand (GFL) receptor Ret. The function of NGF/TrkA signaling in the TrkA population of nociceptors has been extensively studied, and NGF/TrkA signaling is a well established mediator of pain. The GFLs are analgesic in models of neuropathic pain emphasizing the importance of understanding the physiological function of GFL/Ret signaling in nociceptors. However, perinatal lethality of Ret-null mice has precluded the study of the physiological role of GFL/Ret signaling in the survival, maintenance, and function of nociceptors in viable mice. We deleted Ret exclusively in nociceptors by crossing nociceptor-specific $\mathrm{Na}_{v} 1.8 \mathrm{Cre}$ and Ret conditional mice to produce Ret-Na 1.8 conditional knock-out (CKO) mice. Loss of Ret exclusively in nociceptors results in a reduction in nociceptor number and size, indicating that Ret signaling is important for the survival and trophic support of these cells. Ret-Na $1.8 \mathrm{CKO}$ mice exhibit reduced epidermal innervation but normal central projections. In addition, $\mathrm{Ret}-\mathrm{Na} \mathrm{V}_{v} \mathrm{I} \mathrm{CKO}$ mice have increased sensitivity to cold and increased formalin-induced pain, demonstrating that Ret signaling modulates the function of nociceptors in vivo. Enhanced inflammation-induced pain may be mediated by decreased prostatic acid phosphatase (PAP), as PAP levels are markedly reduced in Ret-Na $1.8 \mathrm{CKO}$ mice. The results of this study identify the physiological role of endogenous Ret signaling in the survival and function of nociceptors.

\section{Introduction}

During embryonic development, small-diameter sensory neurons in the dorsal root ganglion (DRG) that are classified as nociceptors express the NGF receptor TrkA and depend on NGF for survival (Johnson et al., 1980; Crowley et al., 1994; Silos-Santiago et al., 1995). During late embryonic and early postnatal life, small-diameter unmyelinated nociceptors (C-fiber nociceptors) diverge into two subpopulations (Molliver et al., 1997). One population continues to express TrkA. In the other population, TrkA expression is downregulated and Ret, the signaling receptor for the GDNF family ligands (GFLs), is upregulated. Nociceptors that express TrkA express neuropeptides, do not bind the lectin

\footnotetext{
Received Nov. 30, 2009; revised Jan. 4, 2010; accepted Jan. 13, 2010.

This work was supported by National Institutes of Health (NIH) Grant R21NS059566 and American Cancer Society Grant IRG-58-010-47 (to J.P.G.); NIH Grants HD047396, DK081644, and DK082531 and Children Discovery Institute Grant MDII2009177 (to S.J.); NIH Grant AG013730 (to E.M.J., J.M.); NIH Grant NS042595 (to R.G.W.); and Biotechnology and Biological Sciences Research Council and World Class University Program Grant R31-2008-000-10103-0 (to J.N.W.). This work was supported by NIH Neuroscience Blueprint Interdisciplinary Center Core Grant P30 NS057105 and George M. O'Brien Center for Kidney Disease Research (P30-DK079333) to Washington University. We thank Amanda Knoten, Angela Lluka, Gary Wu, and Sherri K. Vogt for providing excellent technical assistance and animal care. We thank Maria Elena Morales for preparation of the figures.

Correspondence should be addressed to Judith P. Golden at the above address. E-mail: jgolden@wustl.edu.

DOI:10.1523/JNEUROSCI.5930-09.2010

Copyright $\odot 2010$ the authors $\quad 0270-6474 / 10 / 303983-12 \$ 15.00 / 0$
}

isolectin B4 (IB4), do not express thiamine monophosphatase (TMP), and project to lamina I and lamina II outer $\left(\mathrm{II}_{\mathrm{o}}\right)$ of the dorsal horn, while nociceptors that express Ret do not typically express neuropeptides, do bind IB4, do express TMP, and project to lamina II inner $\left(\mathrm{II}_{\mathrm{i}}\right)$ of the dorsal horn (Molliver et al., 1997; Braz et al., 2002; Zylka et al., 2005). While much is known about the role of NGF/TrkA signaling in the TrkA population of C-fiber nociceptors, notably the well established role of NGF/TrkA signaling in pain (Pezet and McMahon, 2006), little is known of the physiological role of GFL/Ret signaling in the Ret population.

The GFL family includes the following: glial cell line-derived neurotrophic factor (GDNF), neurturin (NRTN), artemin (ARTN), and persephin (PSPN) (Airaksinen and Saarma, 2002). The GFL receptor is a complex consisting of a signaling component, the receptor tyrosine kinase Ret, and a ligand-binding component, a cell surface receptor called GDNF family receptor $\alpha$ (GFR $\alpha 1-4$ ) (Airaksinen and Saarma, 2002). Each GFR $\alpha$ coreceptor binds with high affinity to one of the four ligands and confers ligand specificity to the receptor complex: GDNF-GFR $\alpha 1$, NRTN-GFR $\alpha 2$, ARTN-GFR $\alpha 3$, and PSPN-GFR $\alpha 4$. Ret is the common signaling component of all GFL receptor complexes and is required in partnership with a GFR $\alpha$ coreceptor to form a functional receptor complex. 
GFL/Ret signaling influences sensory neuron survival as well as sensory neuron structure and function in many experimental paradigms (Bennett et al., 1998b, 2000; Airaksinen and Saarma, 2002; Ernsberger, 2008; Malin and Davis, 2008). Perinatal death of Ret-null mice has precluded study of the physiological function of Ret in mature sensory neurons (Schuchardt et al., 1994). To overcome this limitation, we deleted Ret exclusively in the nonpeptidergic IB4-binding subpopulation of C-fiber nociceptors by crossing mice harboring a conditional RET allele (Jain et al., 2006) with mice expressing Cre recombinase under the sodium channel $\alpha$ subunit 1.8 promoter $\left(\mathrm{Na}_{v} 1.8\right.$-Cre $)$ (Stirling et al., 2005), which is expressed exclusively in nociceptors. Analysis of these mice reveals that Ret is required for the survival, trophic maintenance, and normal function of IB4 nociceptors.

\section{Materials and Methods}

Animal generation. Institution approved protocols were followed for all animal studies. Generation of Ret conditional mice with a floxed human RET9 allele followed by the EGFP reporter for identification of cells with Ret deletion were generated as previously described (Jain et al., 2006). To produce mice with conditional Ret deletion in nociceptors, heterozygous mice with one Ret-null allele (Ret ${ }^{T G M}$ or Ret ${ }^{\text {lacz }}$ ) (Enomoto et al., 2001; Gould et al., 2008) knocked into the Ret locus were crossed with Nav1. $8^{\mathrm{Cre} /+}$ mice (Stirling et al., 2005) to produce double heterozygous mice $\left(\mathrm{Ret}^{+/-}: \mathrm{Nav1.8} \mathrm{Cre}^{++}\right)$. Double heterozygous mice were then crossed with Ret conditional mice $\left(\operatorname{Ret}^{\text {RETfloxEGFP/+ }}\right)$ to produce Ret-Nav 1.8 conditional knock-out (CKO) mice (Ret $\left.{ }^{\text {RETfloxEGFP/- }}: \mathrm{Nav1}^{\mathrm{Cre} /+}\right)$ and Ret-Na 1.8 heterozygous control (Het) mice $\left(\operatorname{Ret}^{\text {RETfloxEGFP/+ }}: \mathrm{Nav1} .8^{\mathrm{Cre} /+}\right)$. Note that EGFP reporter expression in these mice indicates that Cre-mediated deletion of the floxed allele has occurred.

Behavior testing. Behavior testing was performed using male and female mice 7-10 weeks of age. Littermates or age-matched control mice of the appropriate genotypes were used. Ret-Na $1.8 \mathrm{CKO}$ mice (Ret ${ }^{R E T f l o x E G F P /-}$ : Nav1. $8^{\mathrm{Cre} /+}$ ) were compared with control mice that harbor at least one functional Ret allele in nonpeptidergic nociceptors. Control mice include Ret-Na 1.8 Het mice $\left(\right.$ Ret $\left.{ }^{R E T f l o x E G F P /+}: \mathrm{Nav} 1.8^{\mathrm{Cre} /+}\right)$ or others obtained in crosses to produce Ret-Nav1.8 CKO mice (i.e., $\operatorname{Ret}^{+/-}: \mathrm{Nav1} .8^{\mathrm{Cre} /+}$, $\operatorname{Ret}^{+/+}: \mathrm{Nav1} 8^{\mathrm{Cre} /+}$, Ret $^{\text {RETfloxEGFP/+}}: \mathrm{Nav1}^{+8^{+/+}}$, etc.). We did not observe any significant difference between $\mathrm{Ret}-\mathrm{Na}_{v} 1.8$ Het mice $\left(\right.$ Ret ${ }^{\text {RETfloxEGFP/+}}$ : Nav1. $8^{\mathrm{Cre} /+}$ ) and these other control mice in behavior tests; therefore, they were combined into a single group and are referred to as control mice. To assess general health, mice were weighed and internal and surface body temperature was recorded. The experimenter was blind to the genotypes of the mice during data acquisition. Before testing, mice were placed in open bottom Plexiglas boxes $(5 \times 5 \times 10$ inches $)$ on an elevated plastic (formalin), wire mesh (von Frey, acetone), or warmed $\left(30^{\circ} \mathrm{C}\right)$ glass (Hargreaves) platform for $1 \mathrm{~h}$ (formalin, acetone) or $2-3 \mathrm{~h}$ (von Frey, Hargreaves).

Formalin test. Mice were given a subcutaneous injection of $10 \mu \mathrm{l}$ of $2.5 \%$ formaldehyde into the plantar surface of the right paw, and spontaneous pain behavior was recorded in 5 min bins for a total of $1 \mathrm{~h}$. Spontaneous pain behavior included shaking, flinching, or licking of the paw as well as holding the paw in an elevated position.

Mechanical sensitivity. Mechanical sensitivity was determined using the von Frey test. Beginning with the smallest filament and continuing from smallest to largest calibrated von Frey filaments were pressed to the plantar surface of the hindpaw until the filament just bent. The withdrawal threshold is defined as the force that produces a withdrawal response in 3 of 5 consecutive applications within one trial. The threshold was determined in 3 trials per hindpaw with a 15 min interval between trials. Tail mechanical sensitivity was measured with an Analgesia-Meter (Ugo Basile; Stoelting) using a modification of the Randall-Selitto test as previously described (Morales and Gereau, 2009). The withdrawal threshold was obtained by averaging the values obtained in 3 trials, which were separated by $15 \mathrm{~min}$.

Noxious heat sensitivity (Hargreaves test). The thermal threshold was determined by measuring the withdrawal latency to a radiant heat source applied to the plantar surface of the hindpaw in 5 separate trials for each hindpaw with a $15 \mathrm{~min}$ interval between trials. The withdrawal threshold was determined by averaging the withdrawal latency obtained in each of the trials.

Cold sensitivity. Sensitivity to a cold stimulus was measured using the acetone test. One drop of acetone was applied to the plantar surface of the hindpaw using a $1 \mathrm{ml}$ syringe. Mice were observed for $5 \mathrm{~min}$ after each acetone application. Spontaneous pain behavior (defined as above in the formalin test) that occurred within $5 \mathrm{~min}$ after acetone application was counted as a positive response. Spontaneous pain behavior that occurred within the first $15 \mathrm{~s}$ after acetone application was not counted, since most mice had some reaction to the initial application. In addition, the amount of time spent in pain behavior was recorded. Five trials were performed on each hindpaw with a 5 min interval between trials.

Thermal preference (gradient). Mice were tested in a thermal gradient apparatus with zone temperatures ranging from $9^{\circ} \mathrm{C}$ to $51^{\circ} \mathrm{C}$ as described previously (Dhaka et al., 2007). The temperature zone in which mice spend the most time during the $2 \mathrm{~h}$ test is defined as the "preferred temperature."

Gross motor function (rotarod). An accelerating rotarod (Ugo Basile) was used to evaluate motor coordination and balance. Five consecutive acceleration trials were performed with a 5 min interval between trials as described previously (Montana et al., 2009).

Sensorimotor battery. Tests in the sensorimotor battery were used as previously described to evaluate balance, strength, coordination, and movement (Jain et al., 2006).

Locomotor activity (open field). Locomotor activity was measured in an open field using a VersaMax Animal Activity Monitoring System (AccuScan Instruments). Mice were habituated to the test room in their cages for $1 \mathrm{~h}$ before testing. Locomotor activity was assessed by recording photobeam breaks in a $42 \mathrm{~L} \times 42 \mathrm{~W} \times 30 \mathrm{H}$ cm chamber for $60 \mathrm{~min}$. Total distance traveled, time spent moving, and the number of beam breaks (horizontal activity) were calculated for the entire chamber.

Total L4 DRG neuron counts. Mice were deeply anesthetized and perfused with PBS followed by $4 \%$ paraformaldehyde in PBS. L4 DRGs were removed, rinsed in PBS, and embedded in paraffin. The entire DRG was sectioned at $8 \mu \mathrm{m}$ in the transverse plane, collected in sequence, and stained with $0.25 \%$ cresyl violet. DRG neurons containing one or more nucleoli were counted in every 10th section. The number of neurons counted was multiplied by 10 to obtain the total number. Counts were corrected for split nuclei (Silos-Santiago et al., 1995).

Immunohistochemistry. To take advantage of the EGFP reporter as a marker for neurons in which Ret is deleted, Ret-Nav $1.8 \mathrm{CKO}$ mice and Ret-Na 1.8 Het control mice, each of which contain one floxed Ret allele followed by the EGFP reporter and one Cre allele in the $\mathrm{Na}_{v} 1.8$ locus, were used in immunohistochemistry (IHC) experiments. Foot pad skin was removed from the plantar surface of the hindpaw, immersion fixed in Zamboni's fixative for $2 \mathrm{~h}$, rinsed in PBS, and cryoprotected in $30 \%$ sucrose. Mice were then perfused as described above. DRG and the lumbar enlargement of the spinal cord were removed, rinsed in PBS, and cryoprotected in $30 \%$ sucrose. Skin was sectioned at $30 \mu \mathrm{m}$ in a plane perpendicular to the skin surface. Transverse sections of lumbar spinal cord and DRG (30 and $18 \mu \mathrm{m}$, respectively) were cut on a cryostat and collected on slides. The following antibodies were used: rabbit anti-Ret 1:200 (IBL), rabbit anti-GFP 1:1000 (Invitrogen), rabbit anti TrkA 1:300 (Millipore), rabbit anti- $\beta$ III tubulin (Covance), goat anti-GFR $\alpha 2$ and GFR $\alpha 3$ (1:200 and 1:50, respectively R\&D Systems), and goat anti-CGRP 1:400 (Serotec). Alexa conjugated to IB4 (1:100) (Invitrogen) was used for IB4 labeling.

Neuron counts in fluorescence-labeled DRG. To determine the percentage of labeled neurons relative to the number of EGFP-positive neurons, labeled profiles and EGFP-positive profiles were counted in at least 3 randomly selected sections (separated by $>50 \mu \mathrm{m}$ ) per DRG. To determine the total number of EGFP-, $\beta$ III tubulin-, or TrkA-positive neurons, $18 \mu \mathrm{m}$ sections of the entire DRG were collected in series. Neurons were counted in every fourth section, and the number of neurons was multiplied by 4 to obtain the total number.

Epidermal innervation density. The dermal-epidermal border was traced and the length determined using MetaMorph software. Labeled 

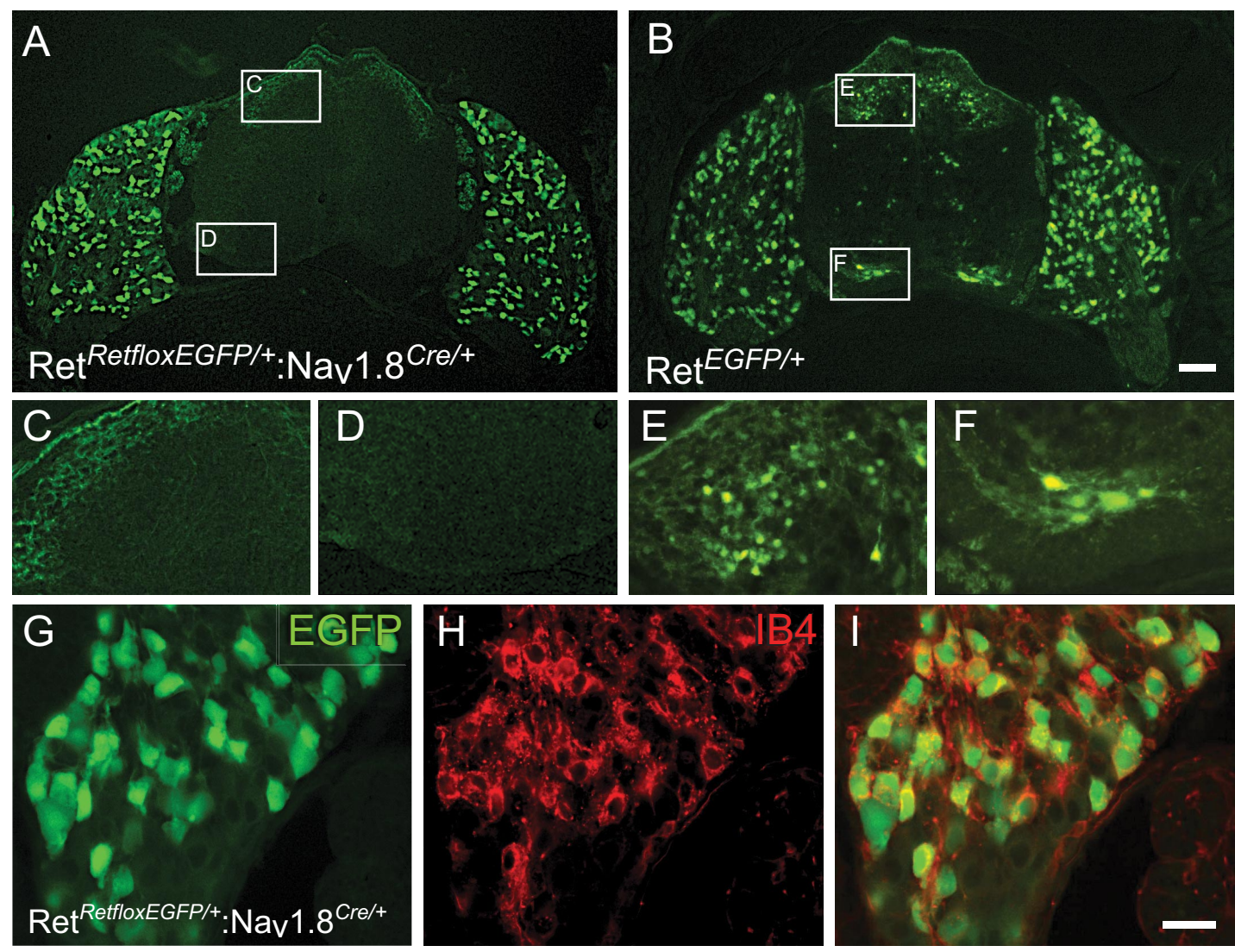

Figure 1. The conditional Ret allele is deleted with high efficiency and specificity in nonpeptidergic nociceptors by Cre expressed from the $\mathrm{Na}_{v} 1.8$ locus. $A, C, D$, Transverse sections of spinal cord and DRG from PND 0 mice showing EGFP expression restricted to the DRG $(\boldsymbol{A})$ and to afferents in the superficial laminae of the dorsal horn $(\boldsymbol{C})$ and no EGFP in motor neurons $(\boldsymbol{D})$ in the Ret-Na 1.8 Het mouse. $\boldsymbol{B}, \boldsymbol{E}, \boldsymbol{F}$, EGFP expression in DRG neurons $(\boldsymbol{B})$, motor neurons in the ventral horn $(\boldsymbol{F})$, and cell bodies in the dorsal horn $(\boldsymbol{E})$ of the Ret ${ }^{E G F P /+}$ reporter mouse. G-I, PND 1 DRG from a Ret-Na 1.8 Het mouse showing virtually complete overlap of EGFP expression (G) with IB4 label $(\boldsymbol{H})$. Images in $\mathbf{G}-\boldsymbol{I}$ are representative of 3 mice. Scale bars: $\boldsymbol{A}, \boldsymbol{B}, 100 \mu \mathrm{m} ; \mathbf{G}-\boldsymbol{I}, 30 \mu \mathrm{m}$.

nerve fibers in the epidermis were counted and the fiber density (\# of fibers/unit of dermal-epidermal border) was calculated (Lindfors et al., 2006).

TMP histochemistry. Frozen spinal cord sections $(30 \mu \mathrm{m})$ were incubated for $30 \mathrm{~min}$ at room temperature in Tris maleate buffer containing $0.08 \%$ lead nitrate and $0.25 \%$ thiamine monophosphate chloride (Sigma) and developed in a $1 \%$ aqueous solution of sodium sulfide (Akkina et al., 2001).

Microscopy. All images were captured using an upright microscope equipped for epifluorescence microscopy (Nikon 80i; CoolSnapES camera) and were processed using MetaMorph or Adobe Photoshop software using global adjustments in brightness and contrast.

Quantitative real-time PCR. RNA was purified from lumbar DRG from adult $R e t-N a_{v} 1.8 \mathrm{CKO}$ and control mice. RNA $(1 \mu \mathrm{g})$ was reverse transcribed using M-MLV Reverse Transcriptase (Invitrogen). Quantitative real-time PCR (qRT-PCR) was performed using Fast SYBR Green Master Mix (Applied Biosystems), and reactions were run in an Applied Biosystems 7900HT Real Time Thermal Cycler. All reactions were run in triplicate, and relative fold changes in RNA amount were calculated by the $\triangle \Delta C T$ method using GAPDH to normalize samples (Livak and Schmittgen, 2001).

Real-time PCR (qRT-PCR) primer sequences are as follows $\left(5^{\prime} \rightarrow 3^{\prime}\right)$ : RET: F, ACACCTTCGGACTCACTGCT; R, CAGGGGTGTCTCCTCTTCTG; GAPDH: F, TGCCCCCATGTTTGTGATG; R, TGTGGTCATGAGCCCTTCC; prostatic acid phosphatase (PAP): F, CTCGAAATATACCTGAGTCCATGCT; R, TGGGAGCTTGAATGTCTACGTTTT. The TRPA1 primer sequence has been previously described by Elitt et al. (2006), and the TRPM8 and TRPV1 primer sequences have been previously described by Albers et al. (2006).

Statistical analysis. Data are reported as the mean \pm SEM. Statistically significant differences were determined using the Student's $t$ test.

\section{Results}

Specific and efficient conditional deletion of Ret in nonpeptidergic nociceptors

Tissue-specific conditional deletion of genes is a powerful strategy to study the function of genes whose embryological loss results in lethality. Ret loss results in perinatal death due to renal agenesis (Schuchardt et al., 1994). We reasoned that generating mice expressing a conditional RET allele (RETfloxEGFP) and the nociceptor-specific $N a_{v} 1.8$ Cre would allow us to study the function of Ret specifically in these neurons. We first determined whether Cre expressed from the $N a_{v} 1.8$ locus could delete the conditional RET allele in an efficient and specific manner. We generated compound heterozygous mice that harbor one RET conditional allele and one Nav1.8 Cre allele $\left(\operatorname{Ret}^{\text {RETfloxEGFP/+ }}\right.$ : Nav1.8 $8^{\mathrm{re} /+}$, "+" denotes the endogenous wild-type mouse allele). This strategy allows simultaneous visualization of the excised allele by direct detection of EGFP signal and fluorescencelabeled markers (including Ret) for nonpeptidergic nociceptors (Jain et al., 2006). In spinal cord and DRG from Ret ${ }^{\text {RETfloxEGFP/+ }}$ : Nav1. $8^{\mathrm{Cre} /+}$ postnatal day (PND) 1 mice, EGFP signal is restricted to DRG neurons and to afferents in the superficial lamina of the dorsal horn where small-diameter DRG neurons terminate, suggesting specific deletion of Ret in nonpeptidergic nociceptors (Fig. $1 A, C, D$ ). EGFP is not detected in motor neurons in the ventral horn of the spinal cord or in sympathetic ganglia in these mice, sites where Ret is known to be expressed, as shown by EGFP signal in Ret-EGFP reporter mice that express EGFP in all Retpositive cells (Fig. $1 A-F$ and data not shown). In addition, we 
observed EGFP expression in spinal dorsal horn neurons in Ret-EGFP reporter mice (Fig. $1 B, E$ ) that is absent in Ret-Nav1.8 CKO mice (Fig. $1 A, C$ ). These results suggest specific deletion of the RET conditional allele in smalldiameter nociceptors.

We determined the efficiency of conditional Ret deletion in small-diameter DRG neurons using IB4 labeling, which overlaps virtually completely with Ret in small-diameter nonpeptidergic DRG neurons (Molliver et al., 1997; Bennett et al., 1998b). IB4 labeling in lumbar DRG from PND 1 Ret-Na 1.8 Het mice $\left(\right.$ Ret $^{\text {RETfloxEGFP/+ }}$ : Nav1. $8^{\mathrm{Cre} /+}$ ) reveals specific and efficient deletion of Ret in IB4-labeled neurons (Fig. 1G-I). Of 560 neurons expressing EGFP (neurons from which Ret is deleted allowing expression of the EGFP reporter from the Ret locus), 557 were labeled with IB4, indicating $>99 \%$ specificity of Ret deletion in the IB4 binding population $(n=3)$. Of 603 IB4-positive neurons, 562 express EGFP, indicating that Ret is excised from $93 \%$ of IB4-positive DRG neurons $(n=3)$. These results indicate that Ret is deleted with high efficiency and specificity in the population of smalldiameter DRG neurons that bind IB4 (nonpeptidergic nociceptors).

We next generated Ret- $N a_{v} 1.8 \mathrm{CKO}$ mice $\left(\right.$ Ret RETfloxEGFP/- $_{\text {Nav1. }}{ }^{\text {Cre/+ }}$ ). Ret$N a_{v} 1.8$ CKO mice were viable, grew normally to adulthood, and were grossly indistinguishable from control littermates that harbor at least one functional Ret allele in nonpeptidergic nociceptors. There was no difference in adult body weight or in internal or surface body temperature between $\operatorname{Ret}-\mathrm{Na}_{v} 1.8 \mathrm{CKO}$ and control mice, consistent with equivalent general health of the two groups (data not shown).

To confirm that Ret is deleted from small-diameter DRG neurons (nociceptors), lumbar DRGs from adult Ret- $\mathrm{Na}_{v} 1.8 \mathrm{CKO}$ and WT mice were labeled with antibodies to Ret (Fig. $2 A, B$ ). In WT DRG, Ret is observed in both large- and small-diameter DRG neurons (Fig. 2A). In Ret-Na $1.8 \mathrm{CKO}$ mice, Ret labeling is absent in small-diameter neurons but remains in large-diameter neurons (Fig. $2 \mathrm{~B}$ ). Ret labeling in DRG from PND 10 Ret-Nav 1.8 CKO mice shows no overlap between EGFP signal (neurons in which Ret is deleted) and Ret immunoreactivity, indicating specific deletion of Ret from nonpeptidergic nociceptors (Fig. $2 C-$ $E)$. As expected, qRT-PCR shows a significant decrease in Ret expression in lumbar DRG from Ret- $\mathrm{Na}_{v} 1.8 \mathrm{CKO}$ mice compared to control mice (Table 1).

\section{Ret regulates nociceptor survival and size}

While GFLs promote survival and provide trophic support to many types of neurons, the physiological role of Ret in small nociceptive DRG neurons has not been examined in adult animals and remains unclear. Studies in GFL- and Gfr $\alpha$ coreceptornull mice have reported variable results (Airaksinen and Saarma, 2002). To determine whether Ret is required for survival and

\begin{tabular}{lc} 
Table 1. Relative changes in gene expression determined by qRT-PCR \\
\hline Gene & Ret CK0 mice (\% of control) \\
\hline Ret & $1 \%^{* *}$ \\
PAP & $47 \%^{*}$ \\
TRPV1 & $113 \%$ \\
TRPA1 & $54 \%$ \\
TRPM8 & $154 \%^{*}$ \\
\hline
\end{tabular}

$n=3$ Ret-Na 1.8 CK0 mice and 5 control mice. ${ }^{*} p<0.05 ;{ }^{* *} p<0.001$.

trophic support of nociceptors, we compared the total number of L4 DRG neurons in adult Ret- $\mathrm{Na}_{v} 1.8 \mathrm{CKO}$ mice and control mice. We found a $33 \%$ decrease in the total number of L4 DRG neurons in Ret-Nav $1.8 \mathrm{CKO}$ mice compared to control mice (Fig. $3 A-C)$. Because small-diameter nonpeptidergic nociceptors are a subset of total DRG neurons, we investigated the extent of neuron loss in the EGFP-positive subpopulation of DRG neurons by counting the total number of EGFP-positive cells. There is a $52 \%$ decrease in the number of EGFP-positive L4 DRG neurons in Ret- $\mathrm{Na}_{v} 1.8 \mathrm{CKO}$ mice compared to Ret- $\mathrm{Na}_{v} 1.8$ Het control mice (Fig. 3D-F).

To determine whether neuron loss in the population of EGFPpositive neurons accounts for the cell loss observed in total neuron counts (33\% above), we counted EGFP- and $\beta$ III 

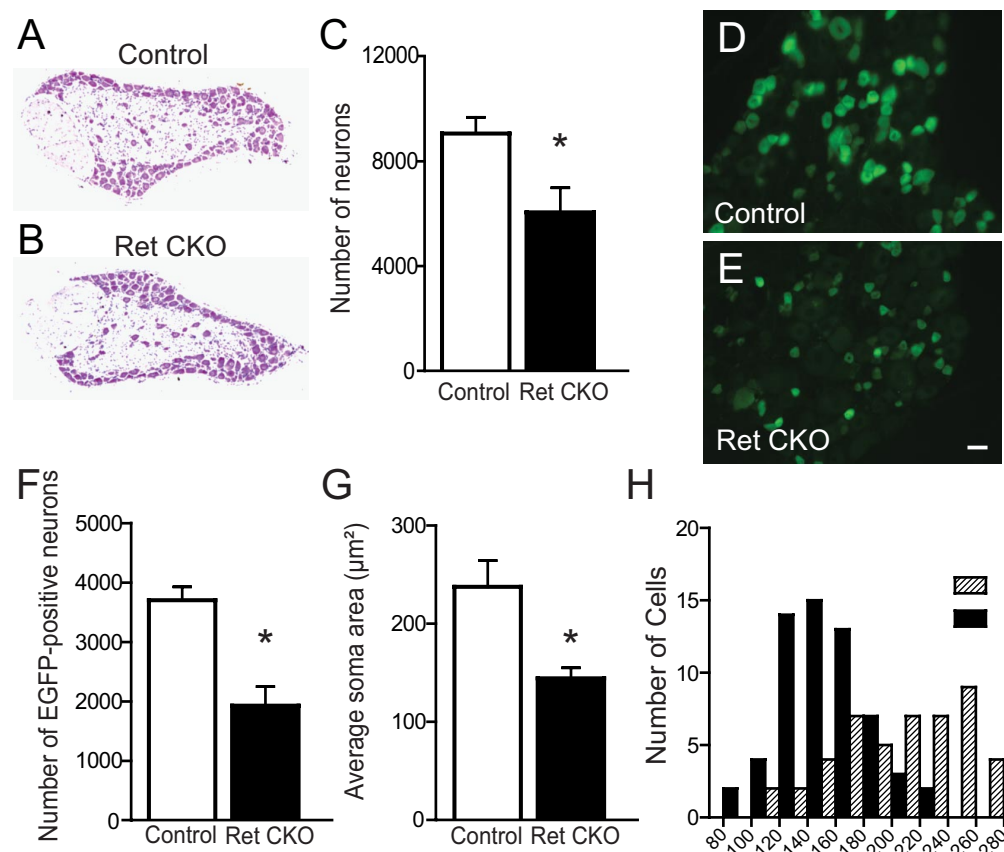

$\mathrm{H}$
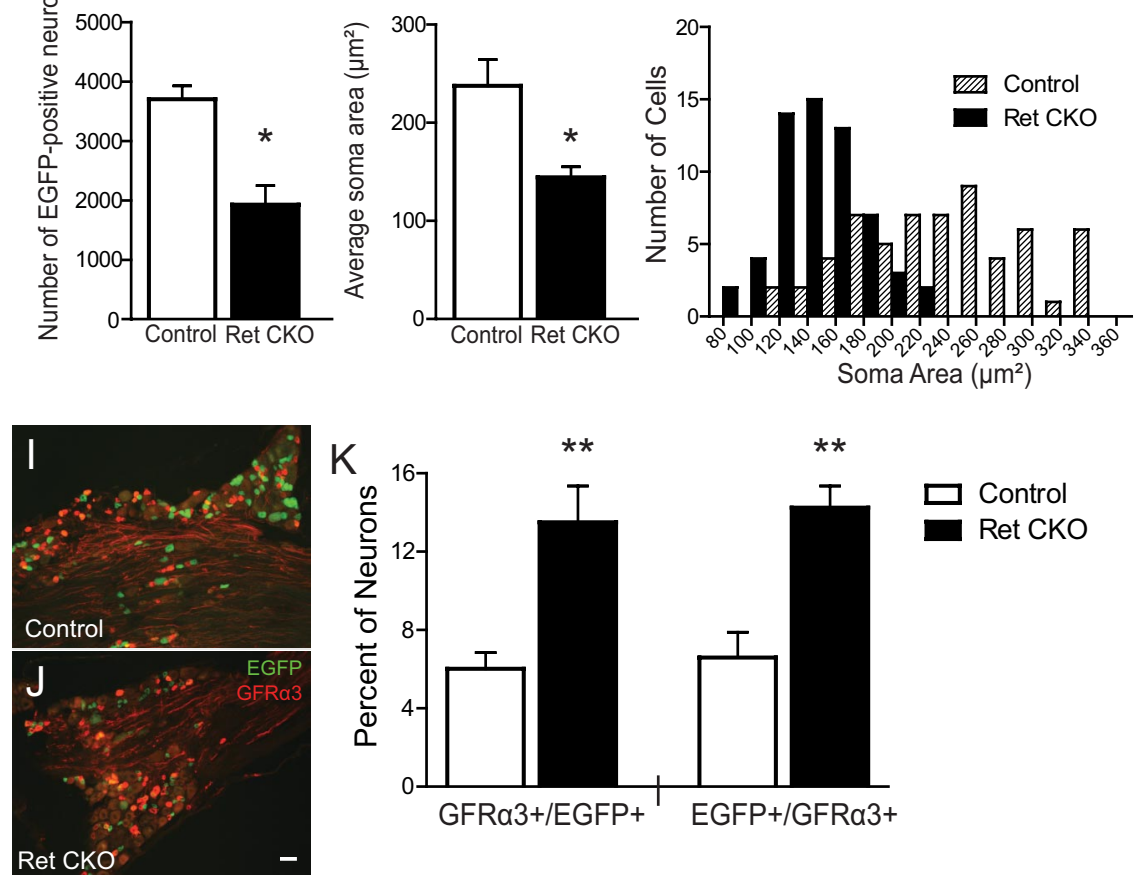

Figure 3. The number and size of nonpeptidergic nociceptors is decreased in Ret-Na $1.8 \mathrm{CKO}$ mice. $\boldsymbol{A}-\mathrm{C}$, The total number of neurons is decreased in the $L 4 \mathrm{DRG}$ of adult Ret-Nav $1.8 \mathrm{CKO}$ mice $(\boldsymbol{B}, \boldsymbol{C} ; n=4)$ compared to control mice $(\boldsymbol{A}, \boldsymbol{C} ; n=8)\left({ }^{*} p<0.05\right)$. $\boldsymbol{D}-\boldsymbol{F}$, The number of EGFP-positive DRG neurons is decreased in $\mathrm{L} 4 \mathrm{DRG}$ of Ret-Na 1.8 CKO mice $(\boldsymbol{E}, \boldsymbol{F})$ compared to Ret-Na 1.8 Het control mice $(\boldsymbol{D}, \boldsymbol{F})\left(\boldsymbol{F}, n=3\right.$ of each; $\left.{ }^{*} p=0.01\right) . \boldsymbol{D}, \boldsymbol{E}, \boldsymbol{G}, \boldsymbol{H}$, The soma area of EGFP-positive DRG neurons is decreased in Ret-Na 1.8 CK0 mice $(\boldsymbol{E})$ compared to Ret-Nav 1.8 Het control mice $(\boldsymbol{D})\left(\boldsymbol{G}, n=3\right.$ of each; $\left.{ }^{*} p<0.05\right)$. $\boldsymbol{H}$, Size frequency analysis of EGFPpositive neurons. I- $\boldsymbol{K}$, EGFP (Ret) and GFR $\alpha 3$ do not overlap extensively in lumbar DRG of Ret-Na 1.8 Het control mice (I). Overlap of EGFP and GFR $\alpha 3$ is also not extensive in Ret-Na 1.8 CKO mice $(J)$ but is significantly increased compared to Ret-Na 1.8 Het control mice $\left(\boldsymbol{K}, n=4\right.$ Ret-Na 1.8 CKO mice, $n=5$ control mice, $\left.{ }^{* *} p<0.01\right)$. In $\boldsymbol{C}, \boldsymbol{F}, \boldsymbol{G}$, and $\boldsymbol{K}$, data are represented as mean \pm SEM. Scale bars: (in $\boldsymbol{E}) \boldsymbol{D}, \boldsymbol{E}, 30 \mu \mathrm{m}$; (in $\boldsymbol{J}) \boldsymbol{I}, \boldsymbol{J}, 50 \mu \mathrm{m}$.

Table 2. Percent of lumbar DRG neurons in which EGFP is colocalized with other markers (mean \pm SEM)

\begin{tabular}{lllllr}
\hline & \multicolumn{2}{l}{$\begin{array}{l}\text { EGFP-positive neurons } \\
\text { expressing other marker }\end{array}$} & & \multicolumn{2}{l}{$\begin{array}{l}\text { Other marker neurons } \\
\text { expressing EGFP }\end{array}$} \\
\cline { 2 - 3 } \cline { 6 - 6 } Marker & Ret CKO & Control & & Ret CKO & \multicolumn{1}{c}{ Control } \\
\hline BIII Tubulin & nd & nd & & $32 \pm 2.1^{* *}$ & $46.7 \pm 2.5$ \\
TrkA & $25 \pm 5.8^{*}$ & $9.3 \pm 2.2$ & & $22.1 \pm 4.3^{*}$ & $10 \pm 2.6$ \\
GFR $\alpha 2$ & $67.7 \pm 0.6$ & $72.9 \pm 4.5$ & & $71.7 \pm 1.5^{* * *}$ & $94.2 \pm 1.1$ \\
GFR $\alpha 3$ & $14.3 \pm 1.1^{* *}$ & $6.6 \pm 1.3$ & & $13.5 \pm 1.9^{* *}$ & $6.0 \pm 0.9$ \\
\hline
\end{tabular}

$n=3$ of each genotype for $\beta$ III tubulin and Gfr $\alpha 2$, and 4 of each genotype for TrkA. For Gfr $\alpha 3, n=4$ Ret-Na $1.8 \mathrm{CKO}$ mice and 5 control mice. ${ }^{*} p \leq 0.05 ;{ }^{* *} p<0.01 ;{ }^{* * *} p<0.001$.

tubulin-positive neurons to determine the percentage of total DRG neurons that are EGFP positive (Table 2). In Ret- $\mathrm{Na}_{v} 1.8 \mathrm{Het}$ mice, EGFP-positive neurons account for $46.7 \pm 2.5 \%$ of total DRG neurons. Loss of $52 \%$ of EGFP-positive neurons would therefore correspond to a $\sim 24 \%$ decrease in total neuron number, accounting for most if not all of the DRG neuron loss in Ret-Na 1.8 CKO mice.

The soma size of DRG neurons is influenced by the expression of GFL ligands and GFL coreceptors (Zwick et al., 2002; Elitt et al., 2006; Lindfors et al., 2006). We compared the soma area of EGFP-positive DRG neurons in Ret-Nav $1.8 \mathrm{CKO}$ and Ret- $N a_{v} 1.8$ Het control mice to determine whether Ret signaling is required for trophic support of nonpeptidergic nociceptors. We found a $39 \%$ decrease in the soma area of EGFP-positive DRG neurons in adult Ret- $\mathrm{Na} a_{v} 1.8 \mathrm{CKO}$ mice compared to Ret-Na 1.8 Het control mice (Fig. $3 D, E, G)$. Size frequency analysis of EGFPpositive neurons suggests that size is decreased across the entire population of EGFP-positive neurons (Fig. $3 H$ ). These results indicate that Ret signaling is required for trophic maintenance of mature nonpeptidergic DRG neurons and is in agreement with findings in adult Gfro2null and PND 14 Ret-Wnt1 CKO mice (Lindfors et al., 2006; Luo et al., 2007).

\section{Ret regulates expression of Gfr $\alpha 3$ in nonpeptidergic nociceptors}

In the DRG, Gfr $\alpha 2$ and Gfr $\alpha 3$ expression is largely restricted to small-diameter neurons, while Gfr $\alpha 1$ is expressed in both large-diameter and small-diameter DRG neurons (Bennett et al., 1998b; Orozco et al., 2001; Stucky et al., 2002; Lindfors et al., 2006; Luo et al., 2007). Because it has been reported that $G f r \alpha 2$ deletion alters sensory function (Stucky et al., 2002; Lindfors et al., 2006) and Ret alters Gfr $\alpha 2$ expression (Luo et al., 2007), we examined Gfr $\alpha 2$ expression in Ret-Na $1.8 \mathrm{CKO}$ mice. We also examined expression of Gfr $\alpha 3$, the other Gfr $\alpha$ coreceptor expressed exclusively in small-diameter DRG neurons (Orozco et al., 2001; Elitt et al., 2006). In agreement with previous reports (Bennett et al., 1998b; Lindfors et al., 2006; Luo et al., 2007), we found that virtually all Gfr $\alpha 2$-positive neurons in $\mathrm{Ret}-\mathrm{Na}_{v} 1.8 \mathrm{Het}$ control mice are also EGFP positive (express Ret) and the majority of EGFP-positive neurons coexpress Gfr $\alpha 2$ (Table 2). Deletion of Ret had no effect on the percentage of EGFP-positive neurons that coexpress Gfr $\alpha 2$, suggesting that Gfr $\alpha 2$ expression is not regulated by Ret in nonpeptidergic nociceptors (Table 2). The percentage of Gfr $\alpha 2$-positive neurons that express EGFP is significantly less in Ret- $\mathrm{Na}_{v} 1.8 \mathrm{CKO}$ mice than in $\mathrm{Ret}-\mathrm{Na} a_{v} 1.8 \mathrm{Het}$ control mice, likely reflecting the loss of EGFP neurons in Ret$N a_{v} 1.8 \mathrm{CKO}$ mice. Surprisingly, we did not find extensive overlap between EGFP (Ret) and GFR $\alpha 3$ in Ret- $N a_{v} 1.8$ Het control mice (Fig. $3 I, K$, Table 2). This is in contrast to previous reports, which have found greater colocalization of Ret and Gfr $\alpha 3$ (Orozco et al., 2001; Luo et al., 2007). We do not believe that our failure to detect significant coexpression of EGFP and Gfr $\alpha 3$ is due to lack of 
$\mathrm{Na}_{\mathrm{v}} 1.8$ expression in Gfr $\alpha 3$-positive neurons, because Gfr $\alpha 3$ is expressed exclusively in small-diameter DRG neurons (Orozco et al., 2001; Elitt et al., 2006) and $\mathrm{Na}_{\mathrm{v}} 1.8$ is expressed in nearly all smalldiameter DRG neurons (Stirling et al., 2005), suggesting significant overlap of $\mathrm{Na}_{\mathrm{v}} 1.8$ and Gfr $\alpha 3$ expression. Deletion of Ret results in an increase in the proportion of Gfr $\alpha 3$-positive neurons that are EGFP-positive (Fig. $3 J, K$, Table 2), suggesting that Ret negatively regulates Gfr $\alpha 3$ expression in small-diameter DRG neurons.

\section{Ret deletion decreases peripheral but not central afferent density of nonpeptidergic nociceptors}

To determine whether neuron loss due to Ret deletion is accompanied by a corresponding loss of peripheral innervation, we quantified the density of EGFP-positive fibers in the epidermis (Fig. $4 A, D, G$ ). Labeling with an anti-EGFP antibody was required to visualize EGFP afferents in the skin. The density of EGFP-positive sensory afferents in the epidermis of Ret-Na $1.8 \mathrm{CKO}$ mice is significantly decreased compared with Ret- $\mathrm{Na}_{v} 1.8 \mathrm{Het}$ control mice. This decrease in nonpeptidergic afferents in the epidermis likely reflects the loss of nonpeptidergic neurons. Surprisingly, the total epidermal fiber density, as determined by the density of $\beta$ III tubulin-positive fibers, is not significantly different in Ret- $N a_{v} 1.8 \mathrm{CKO}$ mice from that in Ret-Na 1.8 Het control mice (Fig. $4 B, E, G$ ). The majority of nerve fibers in the epidermis are from nonpeptidergic DRG neurons that express Ret or from DRG neurons that express the NGF receptor TrkA and coexpress neuropeptides (Zylka et al., 2005). To determine whether expansion of the TrkA/peptidergic fiber population in the epidermis accounts for the normal number of $\beta$ III tubulin-labeled fibers observed in $\operatorname{Ret}-\mathrm{Na}_{v} 1.8$ CKO mice, we compared the density of CGRP-positive fibers in Ret-Na $1.8 \mathrm{CKO}$ mice and Ret-Nav 1.8 Het control mice (Fig. $4 C, F, G)$. We found that there is no difference in the density of CGRP-positive fibers in the epidermis of Ret- $N a_{v} 1.8 \mathrm{CKO}$ and control mice, indicating that expansion of peptidergic afferents does not account for the normal density of $\beta$ III tubulin-labeled epidermal afferents observed in Ret- $N a_{v} 1.8 \mathrm{CKO}$ mice.

In the spinal cord dorsal horn, TrkA (peptidergic) and Ret (nonpeptidergic) afferents are segregated with TrkA afferents occupying lamina $\mathrm{I}$ and lamina $\mathrm{II}_{\mathrm{o}}$ and Ret afferents occupying lamina $\mathrm{II}_{\mathrm{i}}$ (Molliver et al., 1997). Double labeling of EGFP (Ret) and CGRP (TrkA) afferents in the lumbar dorsal horn shows that the non-overlapping pattern of Ret and TrkA afferents observed in lamina I and lamina II of Ret- $\mathrm{Na}_{v} 1.8$ Het control mice is indistinguishable from the pattern observed in Ret- $\mathrm{Na}_{v} 1.8 \mathrm{CKO}$ mice (Fig. 5A-F). In addition, the density of EGFP labeling in Ret$N a_{v} 1.8 \mathrm{CKO}$ mice is similar to Ret- $\mathrm{Na} a_{v} 1.8$ Het control mice, indicating that, in contrast to peripheral projections, the density of the central projections of nonpeptidergic Ret afferents is unchanged in the absence of Ret. Similar results were obtained with higher di- lution of the GFP antibody, suggesting that oversaturation of the fluorescent signal did not obscure loss of EGFP-positive afferents (data not shown). IB4 labeling of nonpeptidergic afferents in the lumbar dorsal horn was also similar in Ret- $\mathrm{Na}_{v} 1.8 \mathrm{CKO}$ mice and Ret- $N a_{v} 1.8$ Het control mice (see Fig. $8 F, G$ ). Therefore, although there is a significant loss of nonpeptidergic neurons in $\mathrm{Ret}-\mathrm{Na} a_{v} 1.8$ CKO mice, the density and topography of the central projections of these neurons in the dorsal horn appear normal. Ret signaling is therefore dispensable for the development and maintenance of central projections from nonpeptidergic DRG neurons, since surviving nonpeptidergic neurons reach their central targets in the absence of Ret.

Ret-Na $1.8 \mathrm{CKO}$ mice have normal responses to mechanical stimuli and noxious heat

To determine whether loss of Ret in nociceptors affects mechanical sensitivity, von Frey testing was performed on Ret-Nav 1.8 $\mathrm{CKO}$ and control mice. There is no difference in hindpaw mechanical sensitivity between $\mathrm{Ret}-\mathrm{Na} \mathrm{a}_{v} 1.8 \mathrm{CKO}$ mice and control mice (Fig. 6A, left). Sensitivity to a noxious mechanical stimulus, determined using a modified Randall-Selitto test, is also not different in Ret- $\mathrm{Na}_{v} 1.8 \mathrm{CKO}$ mice from that in control mice (Fig. $6 \mathrm{~A}$, right). These results indicate that Ret signaling in nonpeptidergic DRG neurons is not required for normal behavioral sensitivity to innocuous or noxious mechanical stimuli. Recent reports demonstrating increased mechanical thresholds in mice in which most/all nonpeptidergic DRG neurons are killed using 


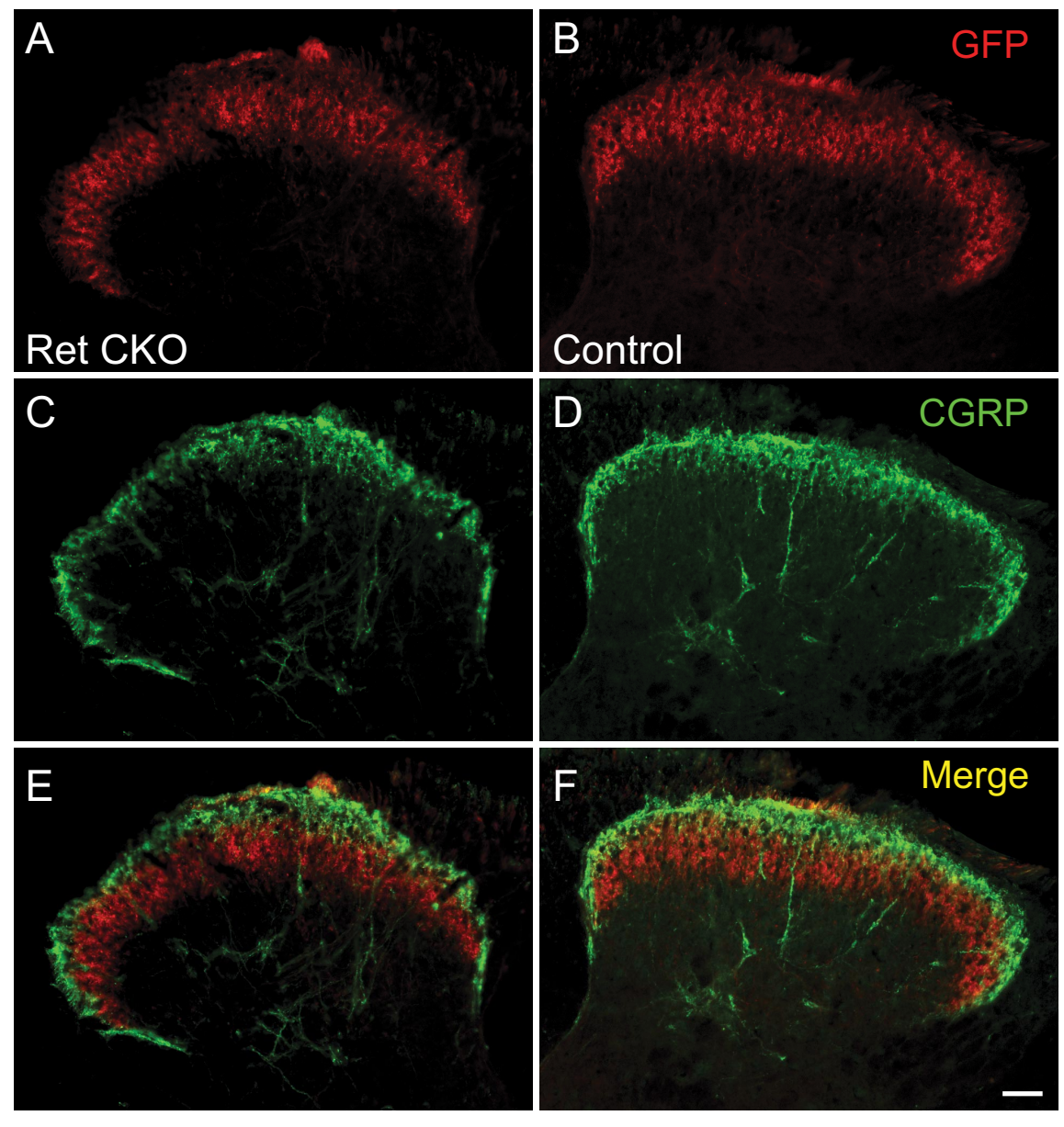

Figure 5. The density and topography of the central projections of nonpeptidergic nociceptors appear normal in $\mathrm{Ret}_{-} \mathrm{Na}_{v} 1.8 \mathrm{CKO}$ mice. The density and topography of the central projections from nonpeptidergic DRG neurons in the superficial laminae of the lumbar dorsal horn of Ret-Na 1.8 CKO mice $(\boldsymbol{A}, \boldsymbol{C}, \boldsymbol{E})$ are not changed compared with Ret-Na 1.8 Het control mice $(\boldsymbol{B}, \boldsymbol{D}, \boldsymbol{F})$. Photos are representative of four mice of each genotype. Scale bar: (in $\boldsymbol{F}) \boldsymbol{A}-\boldsymbol{F}, 50 \mu \mathrm{m}$.

diphtheria toxin (DTA) suggest that nonpeptidergic nociceptors are required for normal mechanical sensitivity (Abrahamsen et al., 2008; Cavanaugh et al., 2009). In Ret- $N a_{v} 1.8$ CKO mice in which $\sim 50 \%$ of nonpeptidergic DRG neurons are lost, we observed no change in mechanical sensitivity, indicating that $50 \%$ or less of the normal number of non-peptidergic DRG neurons is sufficient to maintain normal mechanical sensitivity.

Previous studies suggest that GFL/Ret signaling may modulate noxious heat transduction in IB4 nociceptors (Stucky et al., 2002; Lindfors et al., 2006). We found that noxious heat sensitivity, as measured by the Hargreaves test, is not different between Ret- $\mathrm{Na}_{v} 1.8 \mathrm{CKO}$ and control mice $(9.2 \pm 0.5 \mathrm{~s}, 8.8 \pm 0.3 \mathrm{~s}$, respectively; $p=0.4$; Ret $-N a_{v} 1.8 \mathrm{CKO}, n=25$, control, $\left.n=55\right)$. Consistent with this finding, qRT-PCR analysis reveals no change in the expression of the noxious heat-activated channel TRPV1 in Ret- $\mathrm{Na}_{v} 1.8 \mathrm{CKO}$ mice compared to control mice (Table 1). Because male and female mice respond differently to noxious thermal stimuli (Mogil et al., 2000), we analyzed data from male and female mice separately. There was no difference between Ret$N a_{v} 1.8 \mathrm{CKO}$ and control mice in the male or female group (Fig. $6 \mathrm{~B}$ ). As previously reported, male control mice had significantly longer withdrawal latencies than female control mice (Mogil et al., 2000). Thermal preference, measured using a thermal gradient apparatus, was not different in male or female Ret- $N a_{v} 1.8$ $\mathrm{CKO}$ from that in control mice (supplemental Fig. S1, available at www.jneurosci.org as supplemental material).
Ret-Na $1.8 \mathrm{CKO}$ mice show increased sensitivity to cold (acetone)

To determine whether Ret loss in nonpeptidergic nociceptors influences sensitivity to a cold stimulus, we assessed cold sensitivity in Ret-Na $1.8 \mathrm{CKO}$ mice and control mice using the acetone test. Female Ret-Na $1.8 \mathrm{CKO}$ mice respond to a significantly greater percentage of acetone applications than female control mice (Fig. 6C). In addition, the total amount of time spent in pain-like behavior is significantly greater for female Ret-Na $1.8 \mathrm{CKO}$ mice than for female controls (Fig. 6D). In contrast, male Ret- $\mathrm{Na} a_{v} 1.8 \mathrm{CKO}$ mice are not different from male control mice (Fig. $6 C, D)$. This result suggests that disruption of Ret signaling in nonpeptidergic DRG neurons in female Ret-Nav1.8 CKO mice results in greater sensitivity to cold and is consistent with the observation that a mixed group of male and female Gfro2null mice show increased sensitivity to cold (Lindfors et al., 2006). In addition, our findings suggest that cold sensitivity may be influenced by gender. This possibility is consistent with a recent report of gender-based differences in cold sensitivity in TRPA1-null mice (Kwan et al., 2006).

Our results suggest that Ret signaling in nonpeptidergic nociceptors regulates cold sensation. Alternatively, loss of nonpeptidergic neurons could contribute to increased cold sensitivity in Ret-Na 1.8 $\mathrm{CKO}$ mice. However, this possibility is inconsistent with recent reports in which DTA is used to kill specific subpopulations of DRG neurons and cold sensitivity is either abolished or unchanged (Abrahamsen et al., 2008; Cavanaugh et al., 2009). Examination of the expression of the cold-activated channels TRPA1 and TRPM8 in Ret-Na 1.8 CKO by qRT-PCR reveals a significant increase only in TRPM8 expression in Ret-Nav $1.8 \mathrm{CKO}$ mice compared to control mice (Table 1). This result suggests that Ret signaling normally suppresses the expression of TRPM8 and that the mechanism underlying increased cold sensitivity in $\operatorname{Ret}-\mathrm{Na}_{v} 1.8 \mathrm{CKO}$ mice may involve TRPM8. Previous reports indicating that TRPM8 is not colocalized with $\mathrm{Na}_{\mathrm{v}} 1.8$ (Abrahamsen et al., 2008) or IB4 (Dhaka et al., 2008) suggest that TRPM8 and Ret are not colocalized and may indicate that modulation of TRPM8 expression by Ret is indirect.

Ret-Na $1.8 \mathrm{CKO}$ mice exhibit increased pain behavior in the formalin test

We performed the formalin test in Ret- $\mathrm{Na} a_{v} 1.8 \mathrm{CKO}$ and control mice to determine whether deletion of Ret in small-diameter DRG neurons affects spontaneous pain behavior induced by inflammation. Ret- $\mathrm{Na}_{v} 1.8 \mathrm{CKO}$ mice have an increased response, compared to control mice, in both phases of the formalin test (Fig. 7). In the first phase of the formalin test, $R e t-N a_{v} 1.8 \mathrm{CKO}$ mice spent $25 \%$ more time engaged in spontaneous pain behavior than control mice. In the second phase, Ret- $\mathrm{Na} a_{v} 1.8 \mathrm{CKO}$ mice spent $\sim 40 \%$ more time engaged in spontaneous pain behavior 
than control mice. These data suggest that Ret signaling in nociceptors attenuates formalin-induced inflammatory pain.

Our results are contrary to the decreased formalin-induced pain behavior observed in Gfro2-null mice. Although decreased cell size suggests Ret signaling is decreased in Gfro2-null mice (Lindfors et al., 2006), it is not known to what extent Ret signaling is impaired in Gfro2-null mice, since many sensory neurons express more than one Gfr $\alpha$ coreceptor. In addition, Ret-Nav $1.8 \mathrm{CKO}$ mice exhibit cell loss and changes in peripheral innervation, which are different from anatomical changes observed in Gfro2null mice. Gfr $\alpha 2$-null mice also are reported to be severely growth retarded, which could influence pain behavior. Therefore, it is not surprising that the phenotypes of these two mutant mice are not identical.

\section{Sensorimotor and motor function is not altered in Ret-Na $1.8 \mathrm{CKO}$ mice} To ensure that behavioral changes observed in Ret-Nav $1.8 \mathrm{CKO}$ are sensory specific and are not related to disturbances of general sensorimotor function or to motor deficits, we performed sensorimotor testing in $\mathrm{Ret}-\mathrm{Na} a_{v} 1.8 \mathrm{CKO}$ mice and control mice. The performance of Ret- $\mathrm{Na}_{v} 1.8 \mathrm{CKO}$ mice is not different from Ret control mice in any of these tests (supplemental Figs. S1, S2, available at www.jneurosci.org as supplemental material).
A

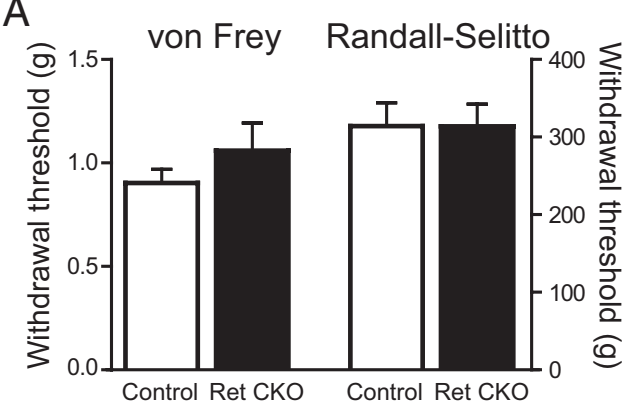

C

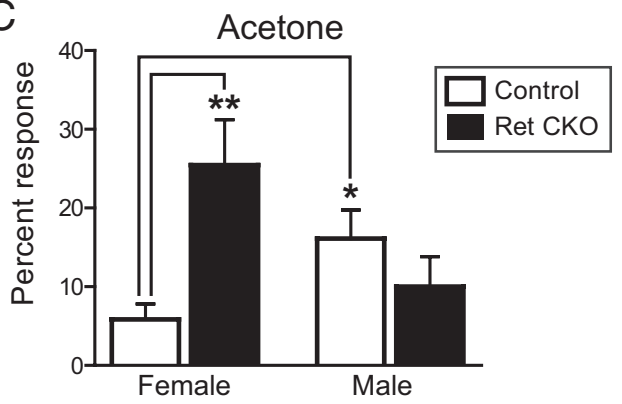

B
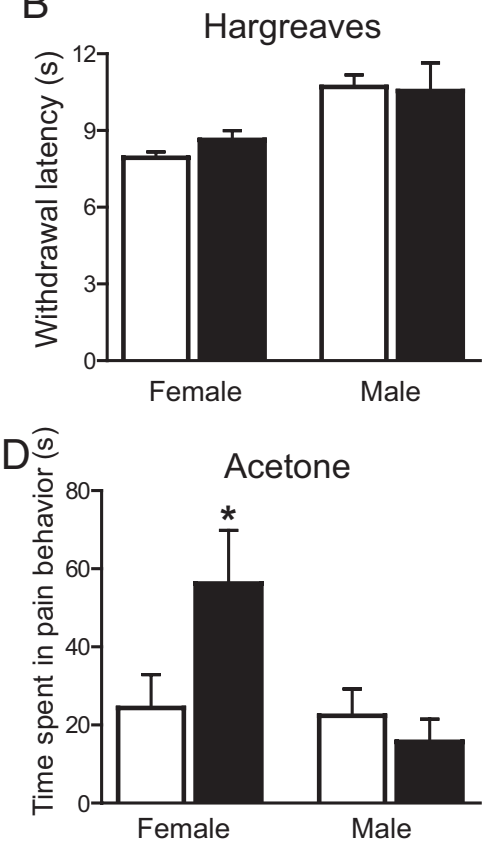

Figure 6. Ret-Na $a_{v} .8$ CKO mice have normal responses to mechanical and noxious heat stimuli but are hypersensitive to a cold stimulus. $\boldsymbol{A}$, Mechanical sensitivity is not changed in Ret- $\mathrm{Na}_{v} 1.8$ CKO mice compared to control mice. Left, von Frey, Ret-Na 1.8 CKO mice, $n=10$; control mice $n=17$. Right, Randall-Selitto, $n=14$ of each genotype. $\boldsymbol{B}$, Noxious heat sensitivity is unchanged in female and male Ret-Na 1.8 CKO mice compared with female and male control mice (females: Ret-Na 1.8 CKO mice, $n=11$; control, $n=38$; males: Ret-Nav 1.8 CKO mice, $n=8$; control, $n=17)$. Female Ret-Na ${ }_{v} 1.8$ CKO and control mice have a significantly shorter withdrawal latency than male Ret-Nav 1.8 CKO and control mice (female vs male Ret-Nav 1.8 CKO mice, $p<0.05$; female vs male control, $p<0.000001)$. $\boldsymbol{C}, \boldsymbol{D}$, Female Ret- $\mathrm{Na}_{v} 1.8$ CKO mice are hyper-responsive to acetone compared to female control mice. C, Female Ret-Na 1.8 CKO mice $(n=11)$ respond to a significantly greater percentage of acetone applications than female control mice $\left.(n=24){ }^{* *} p<0.001\right)$. Male Ret-Na 1.8 CKO mice $(n=10)$ are not different from male controls $(n=18)$ in percentage of responses to acetone applications. Female control mice $(n=24)$ respond to a significantly lower percentage of acetone applications than male control mice $(n=18)\left({ }^{*} p<0.05\right)$. D , Female Ret-Na 1.8 CKO mice $(n=7)$ spend significantly more time engaged in pain behavior than female control mice $(n=11)$ following acetone application ( $\left.{ }^{*} p=0.05\right)$. Male Ret-Na $a_{v} 1.8$ CKO mice $(n=4)$ are not different from male control mice $(n=9)$ in the amount of time spent in pain behavior. Female control mice $(n=11)$ are not different from male control mice $(n=9)$ in the amount of time spent in pain behavior. Data are represented as mean \pm SEM.

TrkA expression is not increased in $\operatorname{Ret}-\mathrm{Na}_{v} 1.8 \mathrm{CKO}$ mice

NGF is a well established mediator of inflammation and attenuation of NGF/TrkA signaling decreases inflammation-induced pain behavior in the formalin test (Pezet and McMahon, 2006; Ugolini et al., 2007). Expanded TrkA expression could therefore explain the enhanced response to formalin observed in Ret$N a_{v} 1.8$ CKO mice. We examined TrkA expression in sensory neurons from which Ret is deleted to determine whether TrkA expression is expanded in this population. In control mice, we found that TrkA is coexpressed in $9.3 \pm 2.2 \%$ of DRG neurons that express Ret (EGFP-positive neurons), consistent with previous reports (Table 2) (Molliver et al., 1997). There is an increase in the percentage of EGFP-positive neurons that coexpress TrkA in Ret-Na $1.8 \mathrm{CKO}$ mice compared with Ret-Na 1.8 Het control mice (Fig. $8 A-C$, left, Table 2). The increase in TrkA coexpression in EGFP-positive neurons could be a result of expansion of TrkA expression in the nonpeptidergic population of nociceptors or may reflect the decreased number of EGFP-positive neurons in Ret- $N a_{v} 1.8 \mathrm{CKO}$ mice. Quantification of the total number of TrkA-positive neurons in lumbar DRG revealed that the total number of TrkA-positive neurons is not different in Ret-Nav 1.8 CKO mice from that in Ret-Na 1.8 Het control mice (Fig. $8 \mathrm{C}$, right). Although the total number of TrkA-positive DRG neurons is not significantly altered in $\mathrm{Ret}-\mathrm{Na}_{v} 1.8 \mathrm{CKO}$, the proportion of TrkA-positive nociceptors is increased due to loss of nonpepti- dergic nociceptors in Ret-Na 1.8 CKO mice. An increase in the proportion of "proinflammatory" TrkA nociceptors may contribute to increased inflammation-induced pain observed in Ret$N a_{v} 1.8$ CKO mice.

\section{Reduced TMP activity in Ret-Na 1.8 CKO mice}

TMP is a well known marker for nonpeptidergic DRG neurons and is known to colocalize extensively with IB4 (Bennett et al., 1998b; Zylka et al., 2008). A recent report has identified TMP as the transmembrane form of PAP, an enzyme that dephosphorylates extracellular AMP to produce the analgesic molecule adenosine (Zylka et al., 2008). PAP-null mice show normal sensitivity to mechanical and noxious thermal stimuli but are hypersensitive in chronic inflammatory and neuropathic pain models. The expression of PAP specifically in nonpeptidergic DRG neurons and the similar behavior phenotypes of $P A P$-null mice and Ret$N a_{v} 1.8$ CKO mice suggested the possibility that Ret signaling might influence PAP expression or activity. We performed TMP histochemistry and found that TMP staining is greatly reduced in the superficial laminae of the lumbar dorsal horn of Ret-Nav 1.8 CKO mice compared with Ret-Nav 1.8 Het control mice, suggesting that Ret modulates TMP expression and/or activity (Fig. $8 D, E)$. Since the central projections of nonpeptidergic DRG neurons are apparently normal in $\mathrm{Ret}-\mathrm{Na}_{v} 1.8 \mathrm{CKO}$ mice as shown by EGFP (Fig. 5) and IB4 labeling (Fig. $8 F, G$ ), it is unlikely that the 

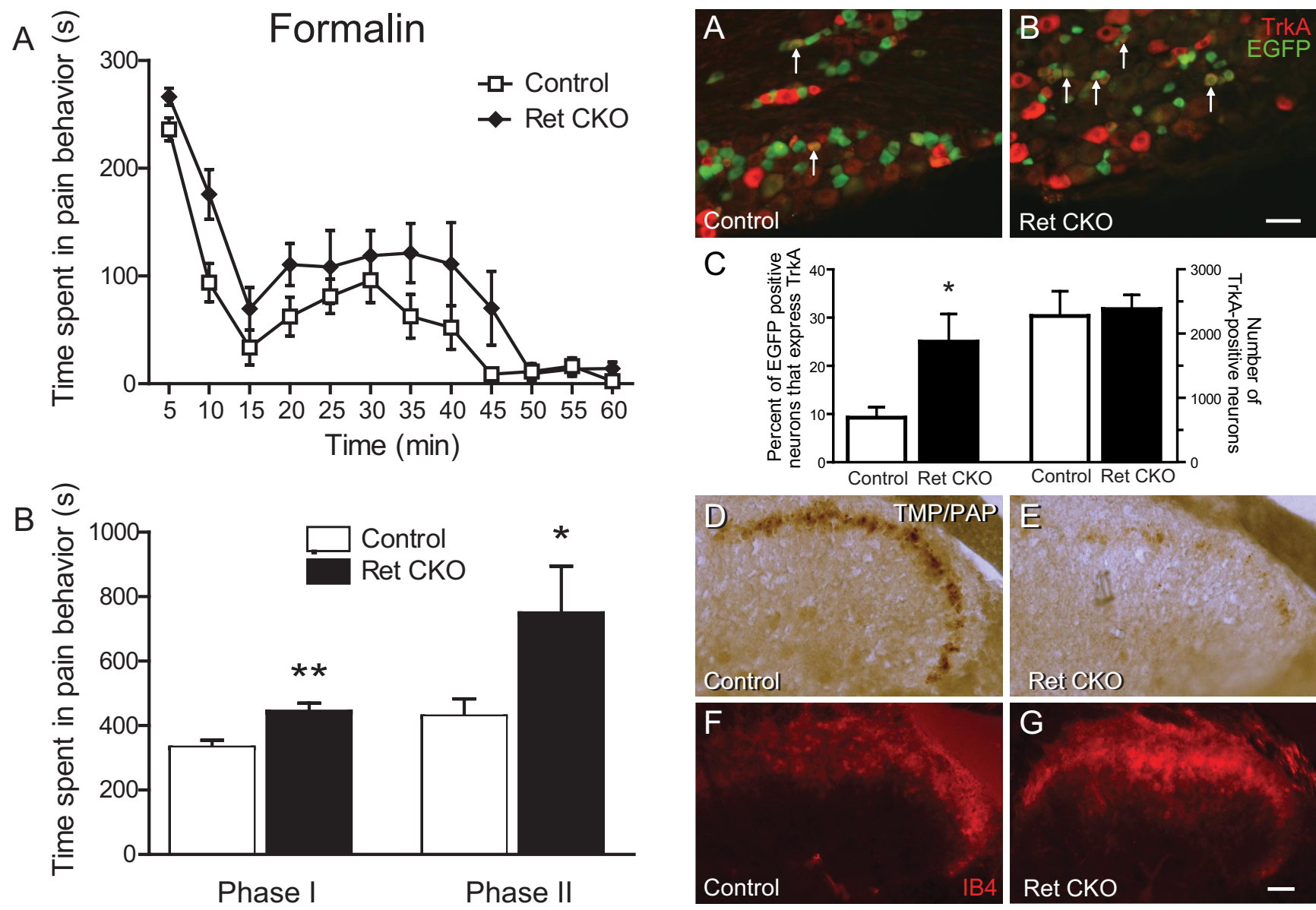

Figure 7. Ret-Nav 1.8 CKO mice exhibit increased formalin-induced pain behavior. Ret$N a_{v} 1.8 \mathrm{CKO}(n=9)$ mice show increased sensitivity to formalin compared to control mice $(n=$ 11). $\boldsymbol{A}$, Time course of spontaneous pain behavior following intraplantar injection of formalin. $\boldsymbol{B}$, Total time spent in spontaneous pain behavior in phase 1 ( $5-10 \mathrm{~min}$ ) and phase 2 (10 - $60 \mathrm{~min}$ ) of the formalin test. Ret-Na $1.8 \mathrm{CKO}$ mice are different from control mice in both phases (phase 1 , ${ }^{* *} p<0.01$; phase $\left.2,{ }^{*} p<0.05\right)$. Data are represented as mean \pm SEM.

decrease in TMP staining is due to loss of nonpeptidergic afferents in the dorsal horn. Using qRT-PCR, we found that PAP expression is significantly decreased in lumbar DRG from Ret$N a_{v} 1.8$ CKO mice compared to control mice (Table 1). These results are consistent with the possibility that Ret positively regulates PAP expression and/or activity and that loss of Ret in nonpeptidergic nociceptors results in a decrease in PAP with a consequent increase in formalin-induced pain.

\section{Discussion}

Specific deletion of Ret in nonpeptidergic nociceptors of Ret$N a_{v} 1.8 \mathrm{CKO}$ mice has, for the first time, provided an opportunity to examine the physiological function of GFL/Ret signaling in nonpeptidergic nociceptors in mature mice. Our results demonstrate that Ret is required for the survival, trophic support, and normal function of nonpeptidergic nociceptors and provide evidence that decreased PAP expression or activity may be the molecular mechanism underlying increased formalin-induced pain following Ret deletion in nociceptors.

\section{Ret signaling is required for survival of} nonpeptidergic nociceptors

Ret expression increases from embryonic day 17 to PND 7 in maturing nonpeptidergic DRG neurons, while TrkA expression

Figure 8. The number of TrkA-positive neurons is unchanged in lumbar DRG from Ret-Na 1.8 CKO and TMP (PAP) expression is decreased in the dorsal horn of the spinal cord of Ret-Na 1.8 CKO mice. The percentage of EGFP-positive neurons that coexpress TrkA is increased in Ret$N a_{v} 1.8$ CKO mice ( $\boldsymbol{B}, \boldsymbol{C}$, left) compared with Ret-Na 1.8 Het control mice $\left(\boldsymbol{A}, \boldsymbol{C}\right.$, left) $\left({ }^{*} p<0.05\right.$, $n=4$ of each genotype). Arrows indicate EGFP/TrkA double-labeled neurons. $C$, Right, The total number of TrkA-positive neurons is not different in Ret-Na 1.8 CKO mice from that in Ret-Na 1.8 Het control mice ( $n=4$ of each genotype). $\boldsymbol{D}, \boldsymbol{E}$, TMP (PAP) is decreased in the superficial laminae of the dorsal horn of the spinal cord in Ret-Na 1.8 CKO mice (E) compared with Ret-Na 1.8 Het control mice (D). IB4 labeling is the same in Ret-Nav 1.8 Het control $(\boldsymbol{F})$ and Ret-Nav 1.8 CKO mice $(\boldsymbol{G})$. Images shown in $\boldsymbol{D}$ and $\boldsymbol{E}$ are representative of eight mice of each genotype, $\boldsymbol{F}$ and $\boldsymbol{G}$ are representative of 6 mice of each genotype. In $\boldsymbol{C}$, data are represented as mean \pm SEM. Scale bars: $\boldsymbol{B}$ (for $\boldsymbol{A}, \boldsymbol{B}), \boldsymbol{G}$ (for $\boldsymbol{D}-\boldsymbol{G}$ ), $50 \mu \mathrm{m}$.

is extinguished between PND 0 and PND 21 (Molliver et al., 1997). A recent study in which Ret was conditionally deleted in DRG neurons using Wnt1-Cre reported that Ret is required for TrkA extinction in nonpeptidergic neurons (Luo et al., 2007). In contrast, we found that TrkA expression is not maintained in nonpeptidergic neurons in adult $\operatorname{Ret}-\mathrm{Na}_{v} 1.8 \mathrm{CKO}$ mice. Although the rate of TrkA extinction is decreased in Ret-Wnt1 CKO mice, TrkA expression is significantly decreased during the first two postnatal weeks in these mice (Luo et al., 2007), suggesting that, in agreement with our results, TrkA extinction occurs in nonpeptidergic DRG neurons in the absence of Ret. In addition, extinction of TrkA expression in nonpeptidergic DRG neurons is reportedly not complete until PND 21 (Molliver et al., 1997). Since Ret-Wnt1 CKO mice die in the third postnatal week it was not possible to determine whether TrkA extinction continues after P14 or whether TrkA extinction is completed in these mice.

Deletion of Ret in nonpeptidergic nociceptors in Ret- $\mathrm{Na}_{v} 1.8$ $\mathrm{CKO}$ mice results in $\sim 50 \%$ loss of these neurons. Although GFL/ Ret signaling is reported to influence sensory neuron survival 
under various experimental conditions (Matheson et al., 1997; Airaksinen and Saarma, 2002; Zwick et al., 2002; Elitt et al., 2006), the role of endogenous GFL/Ret signaling in sensory neuron survival in mature animals is unclear. Analysis of GFL- and GFL coreceptor-null mice has produced inconsistent results (Airaksinen and Saarma, 2002) due to overlapping expression of Gfr $\alpha$ coreceptors in many DRG neurons (Bennett et al., 1998b). Determination of neuron numbers in mice in which Ret is deleted has overcome this confound, since Ret partners with all of the GFL coreceptors.

The incomplete loss of nonpeptidergic DRG neurons in Ret$N a_{v} 1.8$ CKO mice suggests that a subpopulation of nonpeptidergic neurons is not dependent on Ret signaling for survival. DRG neurons become increasingly independent of trophic factors for survival during the first three postnatal weeks, the same period during which the transition from TrkA to Ret expression occurs in nonpeptidergic neurons (Molliver et al., 1997; Vogelbaum et al., 1998). During the transition from TrkA to Ret expression, a subpopulation of nonpeptidergic neurons coexpresses both receptors, raising the possibility that nonpeptidergic neurons that downregulate TrkA late in postnatal development depend on NGF/TrkA signaling for survival in the absence of Ret. In support of this possibility, before TrkA extinction in nonpeptidergic DRG neurons, NGF can support the survival of these neurons in vitro (Molliver et al., 1997), suggesting that NGF/TrkA signaling can substitute for GFL/Ret signaling to maintain survival of nonpeptidergic neurons. Neurons that lose TrkA expression early in the period of transition when they are still trophic factor-dependent likely die in $\operatorname{Ret}-\mathrm{Na}_{v} 1.8 \mathrm{CKO}$ because they lack both Ret and TrkA.

DRG neuron loss was not observed at PND 14 in Ret-Wnt1 CKO mice, suggesting that DRG neuron survival is not dependent on Ret (Luo et al., 2007). However, at P14 TrkA extinction is not yet complete in nonpeptidergic neurons (Molliver et al., 1997). Nonpeptidergic neurons that continue to express TrkA at PND 14 could survive through NGF/TrkA signaling in the absence of Ret. There may be a subpopulation of DRG neurons lost by PND14 in Ret-Wnt1 CKO mice (likely those that downregulate TrkA before PND 14) that is too small to detect.

\section{Central and peripheral projections of nonpeptidergic DRG neurons in Ret-Na $1.8 \mathrm{CKO}$ mice}

Surprisingly, the density of central projections of nonpeptidergic nociceptors appears normal in adult animals despite significant loss of nonpeptidergic DRG neurons in Ret- $\mathrm{Na}_{v} 1.8 \mathrm{CKO}$ mice. One possible explanation for this observation is that surviving nonpeptidergic neurons elaborate additional collateral branches in the dorsal horn to compensate for afferents that are lost with dying neurons. Whether or not these branches form appropriate central connections is unknown and could impact functional changes observed in Ret- $N a_{v} 1.8 \mathrm{CKO}$ mice.

Loss of nonpeptidergic afferents in the epidermis is consistent with the loss of nonpeptidergic neurons observed in $\operatorname{Ret}-\mathrm{Na}_{v} 1.8$ CKO mice. Development of epidermal innervation is dependent on NGF/TrkA signaling and independent of GFL/Ret signaling (Molliver et al., 1997; Patel et al., 2000). Whether the maintenance of peripheral innervation by nonpeptidergic neurons requires GFL/Ret signaling in mature mice is unknown. Although $50 \%$ of nonpeptidergic DRG neurons are lost, $\sim 30 \%$ of the epidermal innervation density from nonpeptidergic fibers is maintained in Ret-Na $1.8 \mathrm{CKO}$ mice, suggesting that the majority of surviving nonpeptidergic neurons maintain target innervation in the absence of GFL/Ret signaling. This indicates that GFL/Ret signaling is not invariably required for the maintenance of peripheral target innervation, although a subpopulation of surviving nonpeptidergic neurons may depend on Ret for maintenance of peripheral projections. Interestingly, NGF/TrkA signaling is required for the maintenance of peptidergic/TrkA fiber innervation of the epidermis in mature animals (Bennett et al., 1998a), revealing diverse requirements for trophic factors in the maintenance of peripheral projections in peptidergic and nonpeptidergic nociceptors in mature animals.

Surprisingly, total epidermal fiber density is not decreased in Ret- $\mathrm{Na}_{v} 1.8 \mathrm{CKO}$ mice. Maintenance of normal epidermal innervation density in Ret-Na $1.8 \mathrm{CKO}$ mice is not due to expansion of TrkA/peptidergic afferents or to increased branching of surviving nonpeptidergic afferents. Because innervation density is regulated by the amount of available trophic factor in the target field (Kessler et al., 1983; Zwick et al., 2002; Elitt et al., 2006), other Ret-expressing axons that respond to GFLs in the skin could potentially extend into areas of the epidermis from which nonpeptidergic fibers are lost, leaving unoccupied target areas of epidermis with available GFLs. Although peptidergic and nonpeptidergic fibers from small-diameter DRG neurons account for the majority of nerve fibers in the epidermis, other fiber types are present (Rice et al., 1998). Some of these, such as sympathetic fibers, express Ret (Airaksinen and Saarma, 2002) and may expand in the epidermis of Ret- $N a_{v} 1.8$ CKO mice.

\section{Ret-Na 1.8 CKO mice exhibit increased formalin-induced pain}

Ret-Nav $1.8 \mathrm{CKO}$ mice exhibit increased formalin-induced pain behavior, suggesting that endogenous Ret signaling in nonpeptidergic nociceptors attenuates inflammation-induced pain. TMP, a well known marker of nonpeptidergic nociceptors, was recently identified as the transmembrane form of PAP (Zylka et al., 2008). PAP expressed on the terminals of nonpeptidergic nociceptors in lamina II of the dorsal horn dephosphorylates extracellular AMP to produce the analgesic molecule adenosine, which activates adenosine $A_{1}$ receptors on lamina II neurons, producing an antinociceptive effect in models of neuropathic and inflammatory pain (Zylka et al., 2008).

The Ret ligands GDNF (Boucher et al., 2000), ARTN (Gardell et al., 2003), and NRTN (our unpublished data) have potent analgesic activity in nerve-injury models of neuropathic pain. Exogenous GDNF restores TMP activity in nonpeptidergic DRG neurons following nerve injury (Bennett et al., 1998b). The identification of the analgesic activity of PAP in nerve injury-induced pain suggests that regulation of PAP expression or activity may be a mechanism by which GFLs produce analgesia after nerve injury. In addition, PAP has analgesic activity in a model of inflammation-induced pain (Zylka et al., 2008). We found that PAP activity is markedly reduced in the dorsal horn of Ret-Na 1.8 $\mathrm{CKO}$ mice (Fig. 8). Our findings suggest that regulation of PAP may be a mechanism by which endogenous GFL/Ret signaling in nonpeptidergic nociceptors modulates inflammation-induced pain behavior.

Previously published studies provide conflicting information as to whether GFLs are proalgesic or analgesic. A number of studies have found that exogenous GFLs administered to nerveinjured animals prevent or reverse neuropathic pain (Boucher et al., 2000; Gardell et al., 2003; Hao et al., 2003; Wang et al., 2003; Pezet et al., 2006). However, there are conflicting reports regarding the effects of exogenous GFLs administered to normal animals. There have been reports that subcutaneous administration of GFLs produces sensitization to noxious stimuli (Malin et al., 
2006; Bogen et al., 2008). However, other studies have reported that subcutaneous administration of GFLs does not alter sensory thresholds (Boucher et al., 2000; Gardell et al., 2003; Hao et al., 2003). Here, we focused on the role of endogenous GFL/Ret signaling in nociceptors in inflammation-induced pain. Our findings suggest that endogenous GFL/Ret signaling in nociceptors attenuates inflammation-induced spontaneous pain. We propose that increased inflammation-induced spontaneous pain in Ret- $\mathrm{Na}_{\mathrm{v}} 1.8$ CKO mice may be due to decreased PAP activity in these mice. This hypothesis is based on the reported analgesic action of PAP in models of both inflammatory and neuropathic pain (Zylka et al., 2008). Our results do not address the possibility that exogenous GFLs do or do not produce hyperalgesia in normal animals. Together with previous studies, our results suggest that modulation of PAP activity may be a mechanism by which GFL/Ret signaling produces analgesia in both inflammation- and nerve injury-induced pain models.

In summary, our results demonstrate that Ret signaling is required for the survival of a subpopulation of small-diameter nonpeptidergic sensory neurons but is dispensable for the development and maintenance of central and peripheral target innervation of surviving nonpeptidergic neurons. Importantly, Ret deletion in nonpeptidergic DRG neurons results in altered cold sensitivity and increased pain following formalin-induced inflammation, indicating that Ret signaling modulates nociceptor function in vivo.

\section{References}

Abrahamsen B, Zhao J, Asante CO, Cendan CM, Marsh S, Martinez-Barbera JP, Nassar MA, Dickenson AH, Wood JN (2008) The cell and molecular basis of mechanical, cold, and inflammatory pain. Science 321:702-705.

Airaksinen MS, Saarma M (2002) The GDNF family: signalling, biological functions and therapeutic value. Nat Rev Neurosci 3:383-394.

Akkina SK, Patterson CL, Wright DE (2001) GDNF rescues nonpeptidergic unmyelinated primary afferents in streptozotocin-treated diabetic mice. Exp Neurol 167:173-182.

Albers KM, Woodbury CJ, Ritter AM, Davis BM, Koerber HR (2006) Glial cell line-derived neurotrophic factor expression in skin alters the mechanical sensitivity of cutaneous nociceptors. J Neurosci 26:2981-2990.

Bennett DL, Koltzenburg M, Priestley JV, Shelton DL, McMahon SB (1998a) Endogenous nerve growth factor regulates the sensitivity of nociceptors in the adult rat. Eur J Neurosci 10:1282-1291.

Bennett DL, Michael GJ, Ramachandran N, Munson JB, Averill S, Yan Q, McMahon SB, Priestley JV (1998b) A distinct subgroup of small DRG cells express GDNF receptor components and GDNF is protective for these neurons after nerve injury. J Neurosci 18:3059-3072.

Bennett DL, Boucher TJ, Armanini MP, Poulsen KT, Michael GJ, Priestley JV, Phillips HS, McMahon SB, Shelton DL (2000) The glial cell line-derived neurotrophic factor family receptor components are differentially regulated within sensory neurons after nerve injury. J Neurosci 20:427-437.

Bogen O, Joseph EK, Chen X, Levine JD (2008) GDNF hyperalgesia is mediated by PLCgamma, MAPK/ERK, PI3K, CDK5 and Src family kinase signaling and dependent on the IB4-binding protein versican. Eur J Neurosci 28:12-19.

Boucher TJ, Okuse K, Bennett DL, Munson JB, Wood JN, McMahon SB (2000) Potent analgesic effects of GDNF in neuropathic pain states. Science 290:124-127.

Braz JM, Rico B, Basbaum AI (2002) Transneuronal tracing of diverse CNS circuits by Cre-mediated induction of wheat germ agglutinin in transgenic mice. Proc Natl Acad Sci U S A 99:15148-15153.

Cavanaugh DJ, Lee H, Lo L, Shields SD, Zylka MJ, Basbaum AI, Anderson DJ (2009) Distinct subsets of unmyelinated primary sensory fibers mediate behavioral responses to noxious thermal and mechanical stimuli. Proc Natl Acad Sci U S A 106:9075-9080.

Crowley C, Spencer SD, Nishimura MC, Chen KS, Pitts-Meek S, Armanini MP, Ling LH, McMahon SB, Shelton DL, Levinson AD (1994) Mice lacking nerve growth factor display perinatal loss of sensory and sympathetic neurons yet develop basal forebrain cholinergic neurons. Cell 76:1001-1011.
Dhaka A, Murray AN, Mathur J, Earley TJ, Petrus MJ, Patapoutian A (2007) TRPM8 is required for cold sensation in mice. Neuron 54:371-378.

Dhaka A, Earley TJ, Watson J, Patapoutian A (2008) Visualizing cold spots: TRPM8-expressing sensory neurons and their projections. J Neurosci 28:566-575.

Elitt CM, McIlwrath SL, Lawson JJ, Malin SA, Molliver DC, Cornuet PK, Koerber HR, Davis BM, Albers KM (2006) Artemin overexpression in skin enhances expression of TRPV1 and TRPA1 in cutaneous sensory neurons and leads to behavioral sensitivity to heat and cold. J Neurosci 26:8578-8587.

Enomoto H, Crawford PA, Gorodinsky A, Heuckeroth RO, Johnson EM Jr, Milbrandt J (2001) RET signaling is essential for migration, axonal growth and axon guidance of developing sympathetic neurons. Development 128:3963-3974.

Ernsberger U (2008) The role of GDNF family ligand signalling in the differentiation of sympathetic and dorsal root ganglion neurons. Cell Tissue Res 333:353-371.

Gardell LR, Wang R, Ehrenfels C, Ossipov MH, Rossomando AJ, Miller S, Buckley C, Cai AK, Tse A, Foley SF, Gong B, Walus L, Carmillo P, Worley D, Huang C, Engber T, Pepinsky B, Cate RL, Vanderah TW, Lai J, et al. (2003) Multiple actions of systemic artemin in experimental neuropathy. Nat Med 9:1383-1389.

Gould TW, Yonemura S, Oppenheim RW, Ohmori S, Enomoto H (2008) The neurotrophic effects of glial cell line-derived neurotrophic factor on spinal motoneurons are restricted to fusimotor subtypes. J Neurosci 28:2131-2146.

Hao S, Mata M, Wolfe D, Huang S, Glorioso JC, Fink DJ (2003) HSVmediated gene transfer of the glial cell-derived neurotrophic factor provides an antiallodynic effect on neuropathic pain. Mol Ther 8:367-375.

Jain S, Golden JP, Wozniak D, Pehek E, Johnson EM Jr, Milbrandt J (2006) RET is dispensable for maintenance of midbrain dopaminergic neurons in adult mice. J Neurosci 26:11230-11238.

Johnson EM Jr, Gorin PD, Brandeis LD, Pearson J (1980) Dorsal root ganglion neurons are destroyed by exposure in utero to maternal antibody to nerve growth factor. Science 210:916-918.

Kessler JA, Bell WO, Black IB (1983) Interactions between the sympathetic and sensory innervation of the iris. J Neurosci 3:1301-1307.

Kwan KY, Allchorne AJ, Vollrath MA, Christensen AP, Zhang DS, Woolf CJ, Corey DP (2006) TRPAl contributes to cold, mechanical, and chemical nociception but is not essential for hair-cell transduction. Neuron 50:277-289.

Lindfors PH, Võikar V, Rossi J, Airaksinen MS (2006) Deficient nonpeptidergic epidermis innervation and reduced inflammatory pain in glial cell line-derived neurotrophic factor family receptor $\alpha 2$ knock-out mice. J Neurosci 26:1953-1960.

Livak KJ, Schmittgen TD (2001) Analysis of relative gene expression data using real-time quantitative PCR and the $2(-\Delta \Delta \mathrm{C}(\mathrm{T}))$ method. Methods 25:402-408.

Luo W, Wickramasinghe SR, Savitt JM, Griffin JW, Dawson TM, Ginty DD (2007) A hierarchical NGF signaling cascade controls Ret-dependent and Ret-independent events during development of nonpeptidergic DRG neurons. Neuron 54:739-754.

Malin SA, Davis BM (2008) Postnatal roles of glial cell line-derived neurotrophic factor family members in nociceptors plasticity. Sheng Li Xue Bao 60:571-578.

Malin SA, Molliver DC, Koerber HR, Cornuet P, Frye R, Albers KM, Davis BM (2006) Glial cell line-derived neurotrophic factor family members sensitize nociceptors in vitro and produce thermal hyperalgesia in vivo. J Neurosci 26:8588-8599.

Matheson CR, Carnahan J, Urich JL, Bocangel D, Zhang TJ, Yan Q (1997) Glial cell line-derived neurotrophic factor (GDNF) is a neurotrophic factor for sensory neurons: comparison with the effects of the neurotrophins. J Neurobiol 32:22-32.

Mogil JS, Chesler EJ, Wilson SG, Juraska JM, Sternberg WF (2000) Sex differences in thermal nociception and morphine antinociception in rodents depend on genotype. Neurosci Biobehav Rev 24:375-389.

Molliver DC, Wright DE, Leitner ML, Parsadanian AS, Doster K, Wen D, Yan Q, Snider WD (1997) IB4-binding DRG neurons switch from NGF to GDNF dependence in early postnatal life. Neuron 19:849-861.

Montana MC, Cavallone LF, Stubbert KK, Stefanescu AD, Kharasch ED, Gereau RW 4th (2009) The metabotropic glutamate receptor subtype 5 antagonist fenobam is analgesic and has improved in vivo selectivity com- 
pared with the prototypical antagonist 2-methyl-6-(phenylethynyl)pyridine. J Pharmacol Exp Ther 330:834-843.

Morales ME, Gereau RW (2009) The effects of tail biopsy for genotyping on behavioral responses to nociceptive stimuli. PLoS One 4:e6457.

Orozco OE, Walus L, Sah DW, Pepinsky RB, Sanicola M (2001) GFR $\alpha 3$ is expressed predominantly in nociceptive sensory neurons. Eur J Neurosci 13:2177-2182.

Patel TD, Jackman A, Rice FL, Kucera J, Snider WD (2000) Development of sensory neurons in the absence of NGF/TrkA signaling in vivo. Neuron 25:345-357.

Pezet S, McMahon SB (2006) Neurotrophins: mediators and modulators of pain. Annu Rev Neurosci 29:507-538.

Pezet S, Krzyzanowska A, Wong LF, Grist J, Mazarakis ND, Georgievska B, McMahon SB (2006) Reversal of neurochemical changes and painrelated behavior in a model of neuropathic pain using modified lentiviral vectors expressing GDNF. Mol Ther 13:1101-1109.

Rice FL, Albers KM, Davis BM, Silos-Santiago I, Wilkinson GA, LeMaster AM, Ernfors P, Smeyne RJ, Aldskogius H, Phillips HS, Barbacid M, DeChiara TM, Yancopoulos GD, Dunne CE, Fundin BT (1998) Differential dependency of unmyelinated and A delta epidermal and upper dermal innervation on neurotrophins, trk receptors, and p75LNGFR. Dev Biol 198:57-81.

Schuchardt A, D'Agati V, Larsson-Blomberg L, Costantini F, Pachnis V (1994) Defects in the kidney and enteric nervous system of mice lacking the tyrosine kinase receptor Ret. [See comment.] Nature 367:380-383.

Silos-Santiago I, Molliver DC, Ozaki S, Smeyne RJ, Fagan AM, Barbacid M,
Snider WD (1995) Non-TrkA-expressing small DRG neurons are lost in TrkA deficient mice. J Neurosci 15:5929-5942.

Stirling LC, Forlani G, Baker MD, Wood JN, Matthews EA, Dickenson AH, Nassar MA (2005) Nociceptor-specific gene deletion using heterozygous NaV1.8-Cre recombinase mice. Pain 113:27-36.

Stucky CL, Rossi J, Airaksinen MS, Lewin GR (2002) GFR $\alpha 2 /$ neurturin signalling regulates noxious heat transduction in isolectin B4-binding mouse sensory neurons. J Physiol 545:43-50.

Ugolini G, Marinelli S, Covaceuszach S, Cattaneo A, Pavone F (2007) The function neutralizing anti-TrkA antibody MNAC13 reduces inflammatory and neuropathic pain. Proc Natl Acad Sci U S A 104:2985-2990.

Vogelbaum MA, Tong JX, Rich KM (1998) Developmental regulation of apoptosis in dorsal root ganglion neurons. J Neurosci 18:8928-8935.

Wang R, Guo W, Ossipov MH, Vanderah TW, Porreca F, Lai J (2003) Glial cell line-derived neurotrophic factor normalizes neurochemical changes in injured dorsal root ganglion neurons and prevents the expression of experimental neuropathic pain. Neuroscience 121:815-824.

Zwick M, Davis BM, Woodbury CJ, Burkett JN, Koerber HR, Simpson JF, Albers KM (2002) Glial cell line-derived neurotrophic factor is a survival factor for isolectin B4-positive, but not vanilloid receptor 1-positive, neurons in the mouse. J Neurosci 22:4057-4065.

Zylka MJ, Rice FL, Anderson DJ (2005) Topographically distinct epidermal nociceptive circuits revealed by axonal tracers targeted to Mrgprd. Neuron 45:17-25.

Zylka MJ, Sowa NA, Taylor-Blake B, Twomey MA, Herrala A, Voikar V, Vihko P (2008) Prostatic acid phosphatase is an ectonucleotidase and suppresses pain by generating adenosine. Neuron 60:111-122. 